\title{
Nobel prize blurs boundaries
}

At first glance it seems that this year's Nobel Prize in Chemistry has gone to a biologist. Roger Kornberg at Stanford University, California, won the prize for unravelling the mysteries of transcription - getting information out of DNA and into proteins via RNA.

His major breakthrough was working out the crystal structure of RNA polymerase II - an enzyme that helps messenger RNA take information from DNA.

People working in the field are thrilled at the news. "Kornberg's work is a tour de force in understanding how transcription works at an atomic level," says Richard Treisman at Cancer Research UK's transcription laboratory in London.

But chemistry bloggers are disgruntled that Kornberg's use of a chemistry tool crystallography - wasenough to warrant a chemistry Nobel prize. Unofficial mutterings from chemistry department corridors confirm some surprise at the choice of recipient. "It is certainly on the biological side of biochemistry, says Malcolm Green, an inorganic chemist from the University of Oxford, UK.

Jesper Svejstrup, a gene-transcription researcher at Cancer Research UK, was a postdoc in Kornberg's laboratory from 1993 to 1996 . "It is unusual to have a single winner," he says. "I think the reason is that it's a chemistry prize. Had the prize been for physiology or medicine it would have been shared with Kornberg'sco-workers, whose roles were more biological, he suggests.

"What we need is a biology prize," jokes Robert Schrock, an inorganic chemist at Massachusetts Institute of Technology, who won

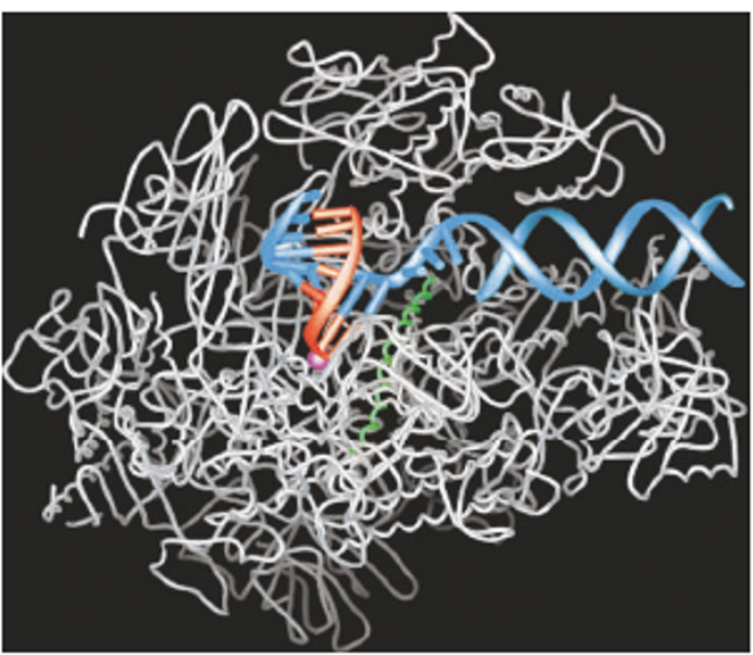

Prizewinning polymerase: but is it chemistry?

the prize for chemistry in 2005. Schrock's prize, shared with Yves Chauvin and Robert Grubbs, was for hard-core chemistry - metathesis, a catalytic reaction used by organic chemists as a way of swapping different groups of atoms in two reacting molecules. This delighted many chemistry fundamentalists, says Schrock, who has heard plenty of grumbles about biology encroaching on chemistry.

The 2005 prize came after a run of bio-related chemistry prizes: in 2002 for determining the structure of biological macromolecules, in 2003 for deciphering channels in cell membranes; and in 2004 for the discovery of the role of ubiquitin in intracellular protein degradation. "Chemistry is becoming more applied," Schrock suggests as one reason for the trend. And, after all, "biology is chemistry," he insists.
Chemistry is evolving naturally, says Schrock. There are fewer developments in basic chemistry than in its biological applications, which means that fundamental contributions to chemistry get less recognition. It's a matter of labels, he says. ${ }^{\circ} \mathrm{Chemistry}$ is only going to become more important - however you want to name it."

The Nobel committee for chemistry 2006 is chaired by a professor of theoretical physical chemistry, Hakkan Wennerström, from Lund University in Sweden. The rest of the members include: a professor of biophysics, a professor of organic chemistry, a professor of molecular biophysics, a professor of physiological chemistry, and a professor of biochemistry. "No surprise that the prize goes to biostuff," laments one blogger.

But Aaron Klug, who has worked with Kornberg and who won the chemistry prize in 1982 for developing crystallographic electron microscopy and working out the structure of nucleic acid-protein complexes, is happy with the choice. "Kornberg certainly thinks like a chemist, ${ }^{,}$he says. ${ }^{\alpha}$ The whole way he handled the RNA polymerase material is beautiful chemistry."

Klug goes as far as to suggest that this year's physiology and medicine prize, awarded to Andrew Fire and Craig Mello for discovering RNA interference, could also have been a chemistry prize. "The question is whether large molecules are part of chemistry. And of course they are."

Katharine Sanderson

\section{Intelligent design gets political}

After a federal courtruled that intelligent design could not be taught in schools in Dover, Pennsylvania, many thought the idea would fade from public view (see Nature 439, 6-7; 2006).

Butintelligent design is reemerging as a political issue. "Itcontinues tohave legs, and we're going to have to worry about it," says Lawrence Krauss, a theoretical physicistat Case Western Reserve University in
Cleveland, Ohio, and chair of the advisory board of Help Ohio Public Education (HOPE), a group that opposes the teaching of intelligent design in the state.

In 2004, the Ohio school board approvedlanguage encouraging a "critical analysis" of evolution and a lesson plan that included arguments used by supporters of intelligentdesign. The plan was repealed shortly after the Dover decision in February, but advocates of intelligent design are again running for positions on the board. In response, HOPE is endorsing itsown candidates. In Michigan, the Republican candidate for state governor, Dick DeVos, has expressed supportfor teaching intelligent design. He is neck-and-neck with the Democratic governor Jennifer Granholm, and the statementmay be aneffort to energize conservatives, says Robert Pennock, president of the pro-evolution Michigan Citizens for Science. "This issue is seen by fundamentalists and evangelicals as part of the culture wars," Pennocksays.

But he thinks the endorsement may backfire: "Economic issues are the most important." By endorsing intelligent design, DeVos could lose the backing of Michigan's thriving biomedical industry.

Geoff Brumfiel 